\title{
De Awb als constante van het bestuurlijk toezicht
}

\author{
Mr. Hansko Broeksteeg
}

\begin{abstract}
Aanbevolen citeerwijze bij dit artikel
Mr. Hansko Broeksteeg, 'De Awb als constante van het bestuurlijk toezicht', Netherlands Administrative Law Library, december 2013, DOI: 10.5553/NALL/.000014
\end{abstract}

Over het algemeen is het bestuursrecht een wat dynamischer vakgebied dan het staatsrecht. Het aantal wetswijzigingen en de hoeveelheid jurisprudentie is in het bestuursrecht aanmerkelijk groter dan in het staatsrecht. Paradoxaal genoeg geldt dat niet voor het bestuurlijk toezicht. Daar waar de bepalingen van Titel 10.2 Awb al sinds 15 jaar een rustig bezit zijn, is het staatsrechtelijke deel van het bestuurlijk toezicht, vastgelegd in voornamelijk de Gemeentewet, aan continue verandering onderhevig. Opvallend is ook dat de wetgever van de derde tranche Awb nauwelijks aandacht wijdt aan het bestuurlijk toezicht.

In deze bijdrage onderzoek ik welke bijdrage de Awb heeft geleverd aan de rechtsontwikkeling van het spontane vernietigingsrecht (Afdeling 10.2.2 Awb), in het bijzonder ten aanzien van gemeenten. ${ }^{1}$ Goedkeuring (Afdeling 10.2.1 Awb) is in de bestuurlijke praktijk aanzienlijk minder relevant gebleken en laat ik daarom buiten beschouwing. Ik begin bij de invoering van de Gemeentewet1994 en de derde tranche Awb (1998) en zal chronologisch de ontwikkeling van het vernietigingsrecht beschrijven. Daarbij ga ik ervan uit dat de lezer de hoofdlijnen van het spontane vernietigingsrecht kent: de Kroon kan een besluit of niet-schriftelijke beslissing van het gemeentebestuur vernietigen wegens strijd met het recht of met het algemeen belang. De burgemeester kan een voordracht tot vernietiging doen. Aan vernietiging kan schorsing vooraf gaan. ${ }^{2}$

\section{Een nieuwe Gemeentewet en een derde tranche Awb}

\subsection{Een nieuwe Gemeentewet}

Op 1 januari 1994 treedt, behalve de (eerste en tweede tranche van de) Awb, ook een nieuwe Gemeentewet in werking. De belangrijkste verandering ten aanzien van het spontane vernietigingsrecht is dat de vernietigingsgrond 'strijd met de wet' wordt gewijzigd in 'strijd met het recht'. Daarmee hoeft minder vaak een beroep te worden gedaan op de vernietigingsgrond 'strijd met het algemeen belang'. Ook nieuw is de mogelijkheid ex art. 281a Gemeentewet tot beroep op de Afdeling bestuursrechtspraak van de Raad van State. De teneur van de gemeentewetgever is dat van bestuurlijk toezicht niet al te lichtvaardig gebruik mag worden gemaakt. 3 De wetgever vindt het bovendien gewenst om de toezichthouder aan een toetsingskader te binden. ${ }^{4}$ In de aanloop naar de inwerkingtreding van de nieuwe Gemeentewet (ook op 1 
januaro 1994) zendt de minister van Binnenlandse Zaken een nota aan de Tweede Kamer over de 'vormgeving en toepassing van het instrument van spontane schorsing en vernietiging', beter bekend als het (eerste) Beleidskader spontane vernietiging. De herziening van dit instrument in de Gemeentewet zou moeten leiden tot een 'versterking van de positie van decentrale overheden bij toepassing van het schorsings- en vernietigingsinstrumentarium' ${ }^{5}$ Volgens de minister vormen spontane schorsing en vernietiging het sluitstuk van het toezichtstelsel. Andere, bijvoorbeeld preventieve toezichtsvormen, komen vaak eerder voor toepassing in aanmerking. Het is bovendien 'een hoogdrempelig instrument: in de heersende opvattingen omtrent de verhoudingen tussen overheden past dat het centrale gezag niet dan met de nodige terughoudendheid van zijn vernietigingsbevoegdheid gebruik maakt'. ${ }^{\mathbf{6}}$ De minister benadrukt dat in de wetgeving enkele waarborgen zijn opgenomen om te bevorderen dat het vernietigingsrecht als een ultimum remedium wordt gebruikt. Zo gaan goedkeurings- en administratiefrechtelijke procedures vóór de toepassing van het vernietigingsinstrument, moet de Kroon het oordeel van de rechter over een bestreden vernietigingsbesluit respecteren, kan een voordracht tot vernietiging alleen worden gedaan met medewerking van de minister van Binnenlandse Zaken - wiens beleid gericht is op terughoudende toepassing - en moet de Raad van State worden gehoord over een voordracht. 7 Uitgangspunt is bovendien dat eerst wordt bezien in hoeverre er aanleiding is te vernietigen wegens strijd met het recht. Vernietiging wegens strijd met het algemeen belang vindt, aldus de minister, zo veel mogelijk plaats tezamen met vernietiging wegens strijd met het recht. $^{\mathbf{8}}$ De nota maakt bovendien duidelijk dat strijd met het recht of het algemeen belang op zichzelf onvoldoende is om vernietiging te rechtvaardigen. Het moet gaan om een inbreuk op de rechtsorde die zodanig is dat een dwingend openbaar belang is gediend met vernietiging. De vernietiging mag voorts geen doel op zichzelf zijn: het beoogt mede met het recht of het algemeen belang strijdige gevolgen te voorkomen. Het toezichthoudend orgaan moet zelf ook de beginselen van behoorlijk bestuur in acht nemen, zoals de rechtszekerheid en het verbod van willekeur.9

Hoewel de wetgever er in de Gemeentewet bewust voor kiest om de vernietigingsgrond strijd met het algemeen belang te handhaven, is de minister hierover in haar nota uitermate kritisch. Vernietiging wegens strijd met het algemeen belang verdraagt zich, aldus de minister, slecht met het gegeven 'dat ook bij lagere overheden beslissingen via democratische besluitvorming tot stand komen en dat deze overheden in voldoende mate vrije beleidsruimte moet worden geboden.' ${ }^{\mathbf{1 0}} \mathrm{Zij}$ beroept zich daarbij op het (niet een ieder verbindende) Europees Handvest inzake Lokale Autonomie (EHLA), dat vernietiging wegens strijd met algemeen belang in beginsel verbiedt. ${ }^{\mathbf{1 1}} \mathrm{Om}$ die reden moet 'uiterste terughoudendheid' worden betracht bij het hanteren van deze vernietigingsgrond. Toch acht het kabinet de tijd niet rijp - het kabinet motiveert niet zulks nader - om met concrete wetsvoorstellen hieromtrent te komen. ${ }^{\mathbf{2}}$

\subsection{En een derde tranche Awb}

Deze Gemeentewet bevat dan nog bepalingen die in 1998 naar Afdeling 10.2.2 van de Awb worden 'overgeheveld'. Zo worden de - reeds grondwettelijk vastgelegde - vernietigingsgronden (strijd met het recht en het algemeen belang) opgenomen in art. 10:35 Awb en is ook de mogelijkheid tot gedeeltelijke vernietiging naar de Awb (art. 10:36) overgebracht. Hetzelfde geldt voor, bijvoorbeeld, de art. 10:37, op grond waarvan een vernietiging niet tegen een 
rechterlijke uitspraak kan ingaan, art. 10:38, op grond waarvan een besluit dat nog goedkeuring behoeft niet kan worden vernietigd, art. 10:39 Awb, dat privaatrechtelijke rechtshandelingen na een bepaalde termijn uitsluit van vernietiging, art. 10:40 en 10:41, die procedurevoorschriften geven, en 10:42 Awb, dat de gevolgen van vernietiging regelt. Deze bepalingen zijn, voor het grootste deel, vrijwel woordelijk uit de Gemeentewet overgenomen. Nieuw is bepaling dat de vernietigingsbevoegdheid slechts kan worden verleend bij de wet (art. 10:34)

De Awb-wetgever is echter uiterst summier over de redenen voor het opnemen van de toezichtsbepalingen in de Awb of over het rechtskarakter van het vernietigingsrecht. Er wordt wel uitleg gegeven van de verschillende instrumenten die het bestuur ter beschikking staan, maar de principiële vraag waarom deze materie in de Awb thuishoort, komt nauwelijks aan bod: de wetgever stelt slechts vast dat de vraag of toezicht noodzakelijk is niet door de Awb-wetgever kan worden beantwoord, maar dat 'de wijze van vestiging van toezicht en regels voor de uitoefening van toezicht zich wel [lenen] voor opneming in de Awb'. ${ }^{\mathbf{3}}$ Een nadere uitwerking krijgt deze constatering niet. Ten aanzien van het rechtskarakter van bestuurlijk toezicht benadrukt de wetgever, specifiek ten aanzien van het vernietigingsrecht, alleen dat het een recht ultimum remedium is. Dat is, zo betoogt hij, een argument om de vernietigingsgronden niet nader te omschrijven. Het vernietigingsrecht 'biedt een mogelijkheid om juist in onvoorziene gevallen in te grijpen.'14 Dat de wetgever zo beknopt is, betekent niet dat opneming van bestuurlijk toezicht in de Awb niet binnen de doelstellingen van deze wet past. Die doelstellingen zijn, kort weergegeven, harmonisatie van bestuursrechtelijke wetgeving, het systematiseren en waar mogelijk vereenvoudigen daarvan, het codificeren van ontwikkelingen in de bestuursrechtelijke jurisprudentie en het treffen van voorzieningen ten aanzien van onderwerpen die zich naar hun aard niet voor regeling in een bijzondere wet lenen.15 Opneming van bestuurlijk toezicht in de Awb betreft (vermoedelijk) vooral de eerste doelstelling: harmonisatie, ofwel het geven van een algemene regeling. De andere doelstellingen lijken minder op bestuurlijk toezicht van toepassing.

\section{Een relatief rustig bezit}

Van 1994 tot 2004 heerst er een stilte voor de storm. De bestuurlijke praktijk en de jurisprudentie zorgen voor een ontwikkeling van het leerstuk, zij het in bescheiden mate. De Greef heeft in een overzichtsartikel de vernietigingsbesluiten geïnventariseerd. ${ }^{\mathbf{1 6}}$ Tussen 1993 en 2004 zijn dat er negentien. ${ }^{17}$ Tevens worden vier besluiten geschorst, waarna geen vernietiging volgt. De Greef concludeert dat, vergeleken met de periode vóór 1993, sprake is van een afname van het aantal vernietigingsbesluiten ${ }^{\mathbf{1 8}}$ en dat derhalve, overeenkomstig het beleidsvoornemen in het Beleidskader, uiterst terughoudend is omgegaan met de bevoegdheid tot spontane vernietiging. Hij signaleert bovendien een eerste voorzichtig gebruik van de mogelijkheid tot beroep bij de Afdeling.

In deze periode (1993-2004) wordt in de rechtspraak en literatuur één inhoudelijk punt bediscussieerd. Dat betreft de reikwijdte van de vernietigingsbevoegdheid. Art. 10:42 Awb bepaalt in lid 1 dat een vernietiging van een besluit zich uitstrekt tot alle rechtsgevolgen waarop het was gericht. Lid 2 schrijft voor dat in het vernietigingsbesluit kan worden bepaald dat de rechtsgevolgen van het vernietigde besluit geheel of ten dele in stand blijven. Dan kan zich de vraag voordoen in hoeverre de Kroon de bevoegdheid heeft om 
het decentrale bestuur voor te schrijven hoe het vernietigingsbesluit moet worden uitgevoerd. In concreto betreft het een tweetal bouwvergunningen, verleend door het college van burgemeester en wethouders van de gemeente Valkenswaard, die worden vernietigd wegens strijd met het recht (art. 44 Woningwet). ${ }^{19}$ De Kroon bepaalt in de vernietigingsbesluiten dat de rechtsgevolgen van het vernietigde besluit niet in stand worden gelaten. Hij adviseert het college om door middel van bestuursdwang het woonhuis af te breken. Daardoor hebben de besluiten ook feitelijke gevolgen. In beroep oordeelt de Afdeling dat de Kroon rechtmatig gebruik heeft gemaakt van de hem toekomende bevoegdheid. ${ }^{\mathbf{2 0}}$ Van der Tang-van Loenen is van mening dat de Kroon niet (zo gedetailleerd) kan bepalen op welke wijze het bestuursorgaan moet omgaan met het vernietigingsbesluit, wanneer het op grond van art. 281 Gemeentewet een nieuw besluit moet nemen. Tak meent echter dat het de Kroon vrij staat om aan te geven wat toelaatbaar is, zodat een nieuwe vernietiging kan uitblijven. ${ }^{\text {11 }}$

Vanaf 2005 en 2006 komt het vernietigingsrecht in een stroomversnelling. Dan doen zich een aantal spraakmakende vernietigings- en schorsingsbesluiten voor, die het instrument van spontane vernietiging en schorsing opnieuw volop in de belangstelling plaatsen. Dat is de vernietiging in de zaken-Lelystad, -Oirschot en -Gorinchem, de schorsing in de zaak-Haarlemmermeer en een vernietiging in de zaak-Limburg. In de eerste drie zaken betrof het vernietiging van rekenkamerverordeningen wegens strijd met het recht. Uit de Gemeentewet zou, aldus de Kroon, zijn af te leiden dat een rekenkamer zelfstandig zijn onderzoeksonderwerpen kiest - en dat de gemeenteraad daarin geen (dwingende) rol mag vervullen. ${ }^{22}$ De Afdeling bevestigde deze interpretatie van de Gemeentewet. ${ }^{\mathbf{2 3}}$ In de literatuur is deze interpretatie ernstig bekritiseerd: zij is niet af te leiden uit de wet en of hier sprake is van een aperte onrechtmatigheid, valt ten zeerste te betwijfelen. De vernietigingsgrond 'strijd met het recht', zo is de strekking, wordt wel erg extensief uitgelegd. ${ }^{\mathbf{2 4}}$ De zaak-Haarlemmermeer speelt in de nasleep van de Schipholbrand in 2005. Naar aanleiding van deze brand trekt de gemeente Haarlemmermeer enkele gebruikersvergunningen, verleend aan de Staat (het ministerie van Justitie), in. Dit besluit wordt door de Kroon geschorst. ${ }^{25}$ Sommigen verwachten dan dat de minister van Justitie tegen de intrekking bezwaar maakt en een voorlopige voorziening bij de bestuursrechter vraagt. ${ }^{\mathbf{2 6}}$ Door niet de gang naar de bestuursrechter te maken, maar tot schorsing van de intrekkingsbesluiten over te gaan, was de gemeente Haarlemmermeer gedwongen een (civielrechtelijk) kort geding aan te spannen tegen de Staat om aldus het schorsingsbesluit aan rechterlijke toetsing te onderwerpen. De rechter laat overigens het besluit in stand. ${ }^{27}$ Damen stelt dat de minister daarmee het speelveld verandert: geen marginale toetsing van de belangenafweging door het college van Haarlemmermeer met als toetsingskader de plicht voor bestuursorganen om handhavend op te treden, maar een marginale toetsing van de belangenafweging die ten grondslag ligt aan het schorsingsbesluit. Anderzijds, zo betoogt Munneke, is de bevoegdheid om tot schorsing en vernietiging over te gaan een discretionaire. Het ultimum remedium-karakter betekent niet dat vernietiging pas een optie mag zijn als de gang naar de bestuursrechter is gemaakt. Met dat karakter wordt vooral een terughoudende toepassing bedoeld. ${ }^{28}$

De zaak-Limburg, ten slotte, betreft een besluit van provinciale staten, waardoor het praktisch onmogelijk wordt om, zonder ontheffing van het college van de gemeente Onderbanken, tot boskap over te gaan. Dit provinciale besluit had in wezen slechts één doel, namelijk boskap in Schinveld, nodig voor het veilig gebruik van een NAVO-vliegbasis net over de grens in Duitsland, tegen te gaan. 
Ook het college van burgemeester en wethouders was mordicus tegen de boskap en zou nooit ontheffing verlenen. De Kroon vernietigt het besluit van provinciale staten wegens strijd met het recht (doorkruising van art. 40 WRO-oud) en strijd met het algemeen belang (noodzakelijke werkzaamheden wegens veilig gebruik van de luchthaven en internationale afspraken worden belemmerd). ${ }^{29}$ Het vernietigingsbesluit houdt bij de Afdeling echter geen stand: vernietiging wegens strijd met het recht kan alleen dan 'indien dat besluit rechtstreeks in strijd is met de wet' - toch een heel ander geluid dan in de Oirschot-zaak! Strijd met het algemeen belang is evenmin aanwezig, omdat boskap uiteindelijk niet onmogelijk is gemaakt. De Kroon is niet bevoegd om tot vernietiging over te gaan, de Afdeling vernietigt op haar beurt het vernietigingsbesluit. ${ }^{\mathbf{3}}$ De zaak krijgt veel media-aandacht.

Met deze vernietigingen staat het instrument (opnieuw) ter discussie. Het betreft dan vooral de discretionaire bevoegdheid van art. 268 Gemeentewet en de vernietigingsgronden van art. 132 lid 4 Gw (herhaald in art. 10:35 Awb). De bepalingen van de Awb doorstaan hun vuurdoop; alleen art. 10:42 zorgt voor jurisprudentie en wetenschappelijke controverse.

\section{Een nieuw Beleidskader}

In 2006 wordt de nota uit 1992 vervangen door een nieuw Beleidskader. ${ }^{31}$ De aanleiding voor dit nieuwe Beleidskader is de Ceteco-affaire, waarin de provincie Zuid-Holland bleek te bankieren. Daarbij kwam de vraag op of de commissaris van de Koningin de (geheime) besluiten van gedeputeerde staten voor vernietiging had moeten voordragen en of hij aan het toen vigerende Beleidskader voldoende houvast zou hebben, vooral ten aanzien van de vernietigingsgronden. Dat houvast werd niet geboden door de Grondwet en evenmin door de Awb. De minister zegt een nieuw Beleidskader toe. ${ }^{\mathbf{3 2}}$ Hij constateert daarin dat het instrument van spontane vernietiging, mede als gevolg van de vernietigingen in de zaken-Haarlemmermeer en -Limburg ${ }^{33}$, de laatste tijd de nodige aandacht heeft gekregen. Het Beleidskader van 1992, waarin weliswaar wordt gepleit voor een terughoudende toepassing van het instrument, werkt, aldus de minister, niet verder uit hoe die terughoudende aanpak gestalte moet krijgen. ${ }^{\mathbf{3 4}}$ Bovendien zijn, nogmaals volgens de minister, sindsdien een nieuwe Provinciewet en Gemeentewet en de Awb in werking getreden. 35

De minister benadrukt in de eerste plaats dat het spontane vernietigingsrecht 'een discretionaire bevoegdheid [is] waarbij de Kroon in haar oordeel nadrukkelijk geacht wordt ook de bestuurlijke opportuniteit te betrekken.' Maar: 'Vernietiging is geen doel op zich en is alleen gerechtvaardigd als er een dwingend openbaar belang met de vernietiging gediend is.' Niet iedere strijd met het recht of met het algemeen belang is, aldus de minister, een grond voor vernietiging: 'Alleen als daarbij tevens de door de Grondwet beoogde bevoegdheidsverdeling in gevaar komt, zal de Kroon het middel inzetten.' Ook in dit Beleidskader wordt het spontane vernietigingsrecht als ultimum remedium aangeduid: 'Daarmee wordt bedoeld dat dit middel alleen gebruikt kan worden als de waarborging van de constitutionele verhoudingen niet op een andere, reguliere manier kan worden gerealiseerd.'36

In het Beleidskader wordt vervolgens uiteengezet wat onder 'strijd met het recht' en 'strijd met het algemeen belang' moet worden verstaan. Strijd met het recht betekent strijd met hogere regels en met algemene rechtsbeginselen. Maar dat is niet voldoende voor vernietiging. 'Alleen wanneer de strijd met het recht een inbreuk maakt op de constitutionele verhoudingen, kan vernietiging aan de orde 
komen.'37 Daarvan is sprake indien een bestuursorgaan van een decentrale overheid een bevoegdheid uitoefent die expliciet aan een hoger orgaan is toevertrouwd, indien dat bestuursorgaan een bevoegdheid uitoefent die de wetgever heeft toevertrouwd aan een ander orgaan binnen hetzelfde overheidsverband en indien dat bestuursorgaan een bevoegdheid uitoefent in strijd met de grond- en mensenrechten. ${ }^{\mathbf{3 8}}$ Strijd met het algemeen belang gaat, zo betoogt de minister, bij voorkeur samen met strijd met het recht. Indien alleen sprake is van strijd met het algemeen belang, zal de Kroon terughoudender moeten optreden. ${ }^{\mathbf{3 9}}$ Van strijd met het algemeen belang is, volgens het Beleidskader, sprake indien het decentrale bestuursorgaan een bevoegdheid claimt die impliciet aan een hoger orgaan is toevertrouwd, indien dat bestuursorgaan weliswaar een bevoegdheid heeft, maar die op een zodanige manier uitoefent dat een aan een hoger orgaan toevertrouwd belang wordt doorkruist en indien dat bestuursorgaan een bevoegdheid uitoefent op een wijze die indruist tegen het belang van de burger..$^{40}$ Verder is er nog een categorie 'overige': 'Met de term “algemeen belang” heeft de grondwetgever de Kroon bewust een eigen beoordelingsruimte willen toekennen. Als gevolg daarvan is het de Kroon niet toegestaan om dit begrip tot in alle details uit te werken. Als dit wel zou gebeuren, wordt de beoordelingsruimte van de Kroon teveel ingesnoerd.'41

Het Beleidskader heeft veel kritiek gekregen. De Jong spreekt van een 'niet tot in alle opzichten consistent verhaal'. ${ }^{42}$ Zo geeft het Beleidskader niet weer wat onder 'grondwettelijke bevoegdheidsverdeling' wordt verstaan. De Grondwet bepaalt, behalve in algemene termen ${ }^{43}$, nauwelijks wat over de bevoegdheidsverdeling tussen Rijk en de decentrale overheden en is uiterst summier over de bevoegdheidsverdeling tussen de ambten van de decentrale overheden. ${ }^{44}$ Volgens De Jong wordt met de constitutionele bevoegdheidsverdeling niets anders bedoeld dan strijd met het recht, alleen zwaarder aangezet door te schermen met begrippen als constitutionele orde en grondwettigheid. Waar het Beleidskader van 1992 nauw aansluit bij de gedachte van de grondwetgever dat het spontane vernietigingsrecht ultimum remedium is, krijgt dit recht in het Beleidskader van 2006 een invulling die niet uit de tekst of de toelichting van de Grondwet of de Gemeentewet is af te leiden. ${ }^{\mathbf{4}}$

Ook de uitleg van het ultimum remedium-karakter is bekritiseerd. Dat betekent niet, zoals het Beleidskader betoogt, dat altijd eerst beroep op de rechter moet worden ingesteld. Dat kan ook welhaast niet, omdat altijd beroep op de rechter openstaat: is het niet de bestuursrechter, dan wel de civiele rechter als restrechter. ${ }^{\mathbf{4 6}}$ Munneke betoogt dat het karakter van ultimum remedium vooral gericht is aan de wetgever, die bij de vormgeving van het wettelijk toezichtsregime ervoor moet waken het vernietigingsrecht zodanig uit te breiden dat dit recht op gespannen voet komt te staan met de lokale autonomie. ${ }^{47}$ Ook is het een oproep aan de Kroon om niet al te lichtvaardig over te gaan tot toepassing van het vernietigingsrecht. Dat is, toegegeven, moeilijk in minder algemene woorden te vatten. Uiteindelijk blijft de toepassing tot op zekere hoogte arbitrair: de bevoegdheid is discretionair en de term 'algemeen belang' is vaag, ondanks nadere invulling met termen als 'dwingend openbaar belang' of 'schending van de constitutionele verhoudingen'. ${ }^{48}$

Ook is kritiek uitgeoefend op de uitleg van 'strijd met het recht'. Niet iedere onrechtmatigheid leidt tot vernietiging, maar alleen als er sprake is van een inbreuk op de constitutionele verhoudingen. Dan is de vraag relevant wat te doen bij 'lichte' strijd met het recht. Hoe kan de strijd met het recht worden opgeheven, indien de betreffende decentrale overheid niet zelf de stappen daartoe zet? Moet de onrechtmatigheid dan blijven voortbestaan? In het geval 
van de illegale villa's in Valkenswaard was strijd met het recht onmiskenbaar aanwezig: het college handelde bewust in strijd met het bestemmingsplan en daarmee met art. 44 Woningwet. Is er echter sprake van een inbreuk op de constitutionele verhoudingen? Hetzelfde geldt voor de vernietigde rekenkamerverordeningen: van constitutionele verhoudingen is geen sprake omdat de rekenkamer niet in de Grondwet wordt geregeld en evenmin deel uitmaakt of voortvloeit uit algemene (ongeschreven) constitutionele beginselen. ${ }^{49}$ De categorie 'overige', ten slotte, ter invulling van strijd met het algemeen belang is wel erg onbepaald en doet in zekere zin afbreuk aan de verdere categorisering van deze vernietigingsgrond.

De wetenschappelijke discussie over het nieuwe Beleidskader had eerst en vooral een staatsrechtelijke insteek. Door bestuursrechtwetenschappers is vrijwel niet deelgenomen aan het discours over het Beleidskader. Redenen daarvoor kunnen zijn dat de bepalingen in de Awb omtrent spontane vernietiging nauwelijks een normatief kader bieden - dat kader biedt eigenlijk eerst het Beleidskader - en dat de onderlinge rechtsbetrekkingen van openbare lichamen relatief weinig bestuursrechtelijke belangstelling ontmoeten..$^{\mathbf{o}}$

\section{Rechtsvormende jurisprudentie}

$\mathrm{Na} 2006$ vinden enkele spraakmakende vernietigingen en schorsingen plaats, alsmede uitspraken van de Afdeling daarover. Interessant is het koninklijk besluit inzake de privatisering van Schiphol, waarin een beslissing van het college van burgemeester en wethouders van de gemeente Amsterdam wordt vernietigd. Die (niet-schriftelijke) beslissing strekt ertoe om op een aandeelhoudersvergadering tegen de statutenwijziging van Schiphol te stemmen, waardoor privatisering van Schiphol geblokkeerd zou worden. ${ }^{\mathbf{5 1}} \mathrm{Het}$ vernietigingsbesluit is drie maanden na de vaststelling van het Beleidskader genomen. In dat Beleidkader is (zie hiervoor) vastgesteld dat een vernietigingsbesluit enkel wegens strijd met het algemeen belang slechts met grote terughoudendheid mag worden genomen. De vernietiging in casu is echter slechts gebaseerd op doorkruising van het rijksbeleid, dat strekt tot privatisering van Schiphol. Van een grotere terughoudendheid van de Kroon blijkt niet (expliciet) uit het vernietigingsbesluit.

Ook in de Landsbanki-zaak wordt enkel wegens strijd met het algemeen belang vernietigd. De zaak betreft het uitwinnen van gelden bij de failliete IJslandse bank Landsbanki door enkele decentrale overheden. Deze overheden hebben deposito's bij de betreffende bank uitstaan. Het besluit tot het uitwinnen van de gelden wordt vernietigd wegens strijd met het algemeen belang. ${ }^{\mathbf{5}^{2}}$ De Kroon overweegt dat de Nederlandse regering een Memorandum of Understanding met de IJslandse regering heeft gesloten, waarin is bepaald dat Nederlandse spaarders (waaronder de betreffende overheden) in aanmerking komen voor een uitkering op grond van het IJslandse depositogarantiestelsel. Over de invulling daarvan onderhandelt de Nederlandse regering dan nog met de IJslandse. De beslissing van de overheden om zelf een procedure te starten, vormt, zo blijkt uit het vernietigingsbesluit, een inbreuk op deze onderhandelingen. Bovendien schaadt zij de gelijkheid van de schuldeisers. De Afdeling oordeelt dat zij in geval van vernietiging wegens strijd met het algemeen belang terughoudend moet toetsen. Tegelijkertijd moet zij, nu beroep op de rechter is opgesteld, wel inhoud geven aan die toetsing. De Afdeling toetst vervolgens heel nauwkeurig en intensief aan de motivering van het vernietigingsbesluit en de door de Kroon gemaakte belangenafweging. Zij vernietigt het vernietigingsbesluit. ${ }^{53}$ In tegenstelling tot eerdere uitspraken, waarin de Afdeling marginaal toetste, toetst 
zij nu vol. Het is dan de vraag of dit een nieuwe lijn is van de Afdeling. Even spraakmakend is de Westland-zaak. De gemeenteraad van Westland verleent voor het gehele grondgebied van de gemeente vrijstelling van het verbod ex art. 2 Winkeltijdenwet om de winkels op zondag te openen. Op grond van art. 3 van deze wet is zulks alleen mogelijk voor gebieden met, kort weergegeven, een autonome toeristische aantrekkingskracht. De burgemeester draagt op grond van art. 273 Gemeentewet het besluit voor vernietiging voor, omdat de gemeente, zijns inziens, onvoldoende toeristisch is. Bij koninklijk besluit van 22 maart 2010 vernietigt de Kroon het besluit van de raad wegens strijd met het recht.54 De daarop volgende uitspraak van de Afdeling is om twee redenen van belang. ${ }^{55}$ In de eerste plaats interpreteert de Afdeling het Beleidskader zeer extensief. De Afdeling stelt dat het begrip 'constitutionele verhoudingen' ruim moet worden uitgelegd. Het Beleidskader ziet, aldus de Afdeling, ook op de door de formele wetgever gegeven bevoegdheidsverdeling. De invulling van de vernietigingsgrond 'strijd met het recht', inhoudende dat een decentraal bestuursorgaan treedt in de bevoegdheid van een ambt van de centrale overheid, moet zo worden geïnterpreteerd, dat hij ook betrekking heeft op het geval waarin een decentraal bestuursorgaan in strijd heeft gehandeld met de door de formele wet gestelde grenzen aan de bevoegdheden die aan het bestuursorgaan zijn gelaten (autonomie) of toebedeeld (medebewind). Daarom, zo concludeert de Afdeling, was de Kroon bevoegd om te toetsen of de raad de hem in de Winkeltijdenwet toebedeelde bevoegdheid juist heeft toegepast. Het gevolg is dat strijd met de wet altijd onder de vernietigingsgrond 'strijd met het recht' valt. En daarmee is het Beleidskader, althans voor wat betreft deze vernietigingsgrond, terzijde geschoven: elke strijd met de wet is voldoende om te vernietigen. De voorwaarde dat het moet gaan om een schending van de 'constitutionele verhoudingen' heeft geen betekenis meer. Een tweede reden waarom deze uitspraak van belang is, is dat de Afdeling weer afstand lijkt te nemen van de intensieve toetsing; zij toetst aanmerkelijk terughoudender dan in de Landsbanki-zaak. De Afdeling treedt niet in de door de Kroon gemaakte belangenafweging, maar toetst 'slechts' of de Kroon van het instrument van spontane vernietiging gebruik kan maken en of hij daarbij het criterium 'autonome toeristische aantrekkingkracht' kan toepassen. Beide vragen beantwoordt de Afdeling bevestigend.

De zaak krijgt nog een staartje met een tweede vernietiging. ${ }^{\mathbf{6}}$ De gemeenteraad van Westland past, op grond van art. 281 Gemeentewet, de winkeltijdenverordening aldus aan dat winkels op zondag open mogen zijn. De juridische constructie is echter anders: geen vrijstelling van het verbod op openstelling, maar een uitbreiding van het gebied waarvoor de vrijstelling eerder reeds gold. Volgens de raad is dit besluit wezenlijk anders dan het eerder vernietigde besluit. De Afdeling denkt daar anders over. Het besluit is slechts 'iets anders vormgegeven' en de 'rechtsgevolgen van beide besluiten zijn dezelfde'.57

Ook hier moet de discussie luiden dat de Awb nauwelijks een (sturende) rol speelde in de jurisprudentie of de wetenschappelijke discussie ten aanzien van het vernietigingsrecht. Deze spitsen zich vooral toe op het Beleidskader uit 2006, meer precies op de uitwerking van de vernietigingsgronden 'strijd met het recht of het algemeen belang', en op de intensiteit van de rechterlijke toetsing van vernietigingsbesluiten.

\section{Een revitalisering van het spontane vernietigingsrecht}

In de jaren 1990 neemt het toezicht in medebewindswetgeving aanzienlijk toe..$^{\mathbf{8}}$ 
Een aantal commissies adviseert over de vraag wat te doen met deze wildgroei aan toezichtsarrangementen. Een Bestuurlijke Werkgroep Alders adviseert over interbestuurlijk toezicht en concludeert, onder meer, dat vernietiging wegens strijd met het algemeen belang feitelijk een inbreuk is op de lokale autonomie. Daarom moet uiterste terughoudendheid worden betracht bij de toepassing van deze vernietigingsgrond. Verder adviseert de Werkgroep om de groei van het specifieke toezicht aan banden te leggen, ten gunste van generiek toezicht, zoals geregeld in de Gemeentewet en de Awb.59 Een Commissie doorlichting en beoordeling van interbestuurlijke toezichtsarrangementen (de commissieOosting) onderzoekt in hoeverre het specifieke toezicht verminderd kan worden. Volgens deze commissie volstaat in beginsel generiek toezicht. Dit toezicht moet dan wel worden herijkt en gerevitaliseerd. Omdat het generiek toezicht als ultimum remedium wordt beschouwd, wordt het weinig toegepast. Dat veroorzaakt de toename van specifiek toezicht. ${ }^{60}$

Het kabinet onderschrijft de conclusies van de commissie-Oosting. Spontane vernietiging zou niet langer een ultimum remedium-karakter moeten hebben. Het Beleidskader moet herijkt, het zou nog te veel de sfeer van restrictie ademen. Het vernietigingsrecht dient, aldus het kabinet, een meer preventieve en proactieve werking te worden gegeven. Mede in het kader daarvan overweegt het kabinet om de bepalingen in de Gemeentewet over spontane vernietiging uit te breiden, bijvoorbeeld met de bevoegdheid voor de Kroon om zelf in de zaak te voorzien. ${ }^{61}$

In 2010 dient de regering het wetsvoorstel revitalisering generiek toezicht in. ${ }^{\mathbf{6 2}}$ $\mathrm{Na}$ een voortvarende parlementaire behandeling treedt de wet - op een enkel onderdeel na - op 1 oktober 2012 in werking. ${ }^{\mathbf{6 3}}$ De Memorie van Toelichting spreekt van een 'breuk met het verleden' en een 'stelselwijziging'. Toezicht is in beginsel beperkt tot de generieke instrumenten die zijn vastgelegd in de Gemeentewet en in het bijzonder tot vernietiging en indeplaatsstelling bij verwaarlozing van medebewindstaken. ${ }^{\mathbf{6 4}}$ Door deze instrumenten centraal te stellen hoopt het kabinet de interbestuurlijke toezichtslast terug te dringen, het vertrouwen van decentrale overheden in de uitoefening van het toezicht te vergroten en stapeling van toezicht te verminderen. ${ }^{\mathbf{6 5}}$ In de Memorie wordt verder aandacht besteed aan het bestaande wettelijke kader, maar de Awb wordt daarin nauwelijks genoemd; de relevante bepalingen worden slechts opgesomd. ${ }^{66}$

Ten aanzien van het vernietigingsrecht stelt het kabinet dat dit recht niet meer als een 'laatste redmiddel' moet worden gezien. Omdat andere (specifieke) instrumenten worden afgeschaft, is het vernietigingsrecht 'het enige instrument (...) om besluiten of niet-schriftelijke beslissingen gericht op enig rechtsgevolg van decentrale bestuursorganen aan te tasten en hun rechtsgevolgen ongedaan te maken.' ${ }^{\mathbf{6} 7}$ De vernietigingsgronden veranderen niet. De gedachte dat vernietiging niet langer ultimum remedium is, vergt geen wetswijziging, wel is een nieuw Beleidskader noodzakelijk. ${ }^{\mathbf{6 8}}$ Het instrument krijgt een aantal 'praktische aanpassingen', om te voorkomen dat vernietigingsprocedures stroperig worden en deze sneller tot een einde te kunnen brengen. ${ }^{\mathbf{6 9}}$ De Kroon krijgt de bevoegdheid om zelf in de zaak te voorzien indien het gemeentebestuur geen beleidsvrijheid heeft. Het betreffende bestuursorgaan hoeft dan geen nieuw besluit te nemen. ${ }^{70}$ De Kroon kan bij het schorsings- of vernietigingsbesluit een voorlopige voorziening treffen, die in de plaats treedt van het geschorste of vernietigde besluit. Dat besluit geldt voor de duur van de schorsing of, in geval van vernietiging, tot het gemeentebestuur een nieuw besluit heeft genomen. ${ }^{\mathbf{1}}$ Zo'n voorziening kan raadzaam zijn, aldus het kabinet, indien schorsing of vernietiging onwenselijke gevolgen heeft. De Kroon kan voorts een aanwijzing 
geven over de uitvoering van het koninklijk besluit. Die moet worden opgevolgd. Indien aan de aanwijzing geen gevolg wordt gegeven, volgt indeplaatsstelling. ${ }^{\mathbf{2}}$ Verder wordt een regeling getroffen, waarbij het provinciebestuur besluiten van het gemeentebestuur voor vernietiging kan voordragen. ${ }^{73}$ De uitvoering van het besluit van het gemeentebestuur wordt maximaal vier weken opgeschort. ${ }^{74}$ Volgens de Memorie van Toelichting heeft de rol van de provincie vooral betrekking op de uitvoering van medebewindstaken. Doorgaans zal dan ook sprake zijn van strijd met het recht. ${ }^{75}$ Het nieuwe Beleidskader zal daarom ook voor het provinciebestuur van belang zijn. De Awb, ten slotte, wordt door deze wet niet herzien. ${ }^{\mathbf{6}}$

Dat is opmerkelijk. De nieuwe artikelen in de Gemeentewet beogen te voorkomen dat procedures stroperig worden en sneller tot een einde kunnen worden gebracht. Met andere woorden: de nieuwe bepalingen willen snellere procedures en definitieve afdoening van het bestuursgeschil bewerkstelligen. In het bestuurs(proces)recht is de afgelopen jaren juist hieraan veel aandacht besteed. De wet aanpassing bestuursprocesrecht, in werking getreden op 1 januari 2013, heeft de Awb op veel punten herzien, onder meer om deze doelen te bereiken. De nieuwe regeling in de Gemeentewet met betrekking tot het zelf (door de Kroon) in de zaak voorzien en het treffen van een voorlopige voorziening, had, naar aard en inhoud, ook in de Awb opgenomen kunnen worden. In de Memorie van Toelichting bij de Wet revitalisering generiek toezicht wordt evenwel aan dit vraagstuk geen aandacht besteed. 77

Met de inwerkingtreding van de Wet revitalisering generiek toezicht op 1 oktober 2012 wordt ook het nieuwe Beleidskader schorsing en vernietiging van kracht. ${ }^{\mathbf{8}}$ Dit Beleidskader verwijst naar het vereiste van het Beleidskader uit 2006, dat vernietiging alleen kan plaatshebben wegens een inbreuk op de constitutionele bevoegdheidsverdeling. Die voorwaarde komt te vervallen. De minister stelt hieromtrent: 'Overweging is dat van de bevoegdheid tot vernietiging eerder gebruik moet kunnen worden gemaakt. Elk besluit dat in strijd met het recht of het algemeen belang is genomen, kan in beginsel worden vernietigd.' Wel geldt dat de Kroon 'steeds aan de hand van alle omstandigheden van het geval een zorgvuldige afweging [dient] te maken van alle bij het besluit betrokken belangen. Daarbij staat proportionaliteit centraal. Een besluit moet alleen worden vernietigd als dit proportioneel is ten opzichte van het doel. Niet iedere strijd met het recht en het algemeen belang is van een zodanig gewicht dat vernietiging gerechtvaardigd is. ${ }^{2} \mathbf{9}$

Onder 'strijd met het recht' wordt strijd met de wet en de algemene rechtsbeginselen verstaan. Dat is, aldus het Beleidskader schorsing en vernietiging, elk hoger recht: de Grondwet, de wet in formele zin, lagere regelgeving, verdragen, EU-recht. ${ }^{80}$ Ook hier benadrukt de minister dat niet elke strijd met het recht tot vernietiging aanleiding geeft. De inbreuk op 'de eigen verantwoordelijkheid van gemeenten en provincies moet proportioneel zijn ten opzichte van het belang dat met vernietiging wordt gediend. (...) Van geval tot geval zal worden beoordeeld of toepassing van het instrument vernietiging proportioneel is.' Van vernietiging wegens strijd met het recht zal eerder sprake zijn 'indien het niet louter de lokale belangen betreft. ${ }^{\mathbf{8 1}}$ Het

Beleidskader geeft als voorbeelden de integriteit van het openbaar bestuur ${ }^{\mathbf{8 2}}$, het belang van de verdeling van bevoegdheden binnen het gemeentebestuur ${ }^{\mathbf{8 3}}$ en de doorkruising van het beleid van het Rijk en de provincie om de Groene Hoofdstructuur te beschermen. ${ }^{\mathbf{8 4}}$

Ten aanzien van de vernietigingsgrond 'strijd met het algemeen belang' sluit het Beleidskader nauw aan bij de eerdere Beleidskaders van 2006 en 1992. De Kroon stelt zich terughoudend op bij vernietiging wegens strijd met het 
algemeen belang. 'Er wordt niet lichtvaardig ingegrepen op de constitutioneel verankerde vrijheid van gemeenten en provincies om de belangen te dienen die aan hen zijn toevertrouwd.' Wanneer sprake is van strijd met het algemeen belang is 'sterk casuïstisch'. Het is aan de Kroon 'om aan de hand van de concrete omstandigheden van het geval een belangenafweging te maken.' Dat betekent, zo betoogt de minister, dat op de Kroon een zware motiveringsplicht rust. De Kroon zal moeten aangeven 'wat de aard van het algemene belang is en waarom het algemeen belang in dat specifieke geval uitgaat boven de belangen die een gemeentelijk of provinciaal bestuursorgaan met zijn besluit beoogt te dienen. ${ }^{\mathbf{8 5}}$ Ook hier geldt dat bovenlokale belangen eerder aanleiding geven tot vernietiging. Dat kunnen zijn internationale verplichtingen, strijd met het beleid van het rijk, het waarborgen van veiligheid of volksgezondheid, et cetera. Het Beleidskader voorziet ten slotte in een soort stappenplan voor het bestuurlijk traject bij vernietiging. ${ }^{86}$

Vooral Munneke heeft de nieuwe regeling van het vernietigingsrecht en het Beleidskader bekritiseerd. Zijns inziens was het criterium 'doorkruising van de constitutionele verhoudingen’ uit het Beleidskader van 2006 weliswaar vaag, maar nodig ter vergroting van de voorspelbaarheid van de toepassing van het vernietigingsrecht en daarmee voor de rechtszekerheid van de betrokken bestuursorganen. Hij stelt dat juist bij een gerevitaliseerd toezicht een dergelijke clausulering extra belangrijk is, maar dat zo'n clausulering in het nieuwe Beleidskader niet terug is te vinden. Proportionaliteit, zo betoogt Munneke, biedt weinig garanties, noch duidelijkheid vooraf: 'Van het vernietigingsrecht kan voortaan dus onbekommerd gebruik worden gemaakt. ${ }^{, 87}$ Ook stelt hij dat terughoudendheid niet aan het beleidskader ten grondslag heeft gelegen. De terughoudendheid zal, zo betoogt Munneke, kunnen blijken uit het stappenplan voor bestuurlijk toezicht: dat biedt de Kroon de mogelijkheid om zijn besluit te heroverwegen. ${ }^{\mathbf{8 8}}$ Munneke bepleit een inhoudelijke normering van de toepassing van het vernietigingsrecht. Dat zou de decentralisatie bevorderen en bijdragen aan de beoogde preventieve werking van het Beleidskader. ${ }^{89}$ Zijlstra heeft soortgelijke kritiek. Daar waar voorgaande Beleidskaders, zo stelt hij, nog min of meer duidelijk konden maken in welke gevallen er zou worden vernietigd, tasten decentrale bestuursorganen met het nieuwe Beleidskader in het luchtledige..$^{90}$

\section{Een nieuwe gerevitaliseerde toepassing?}

Op 12 juli 2012 schorst de Kroon een besluit van het college van burgemeester en wethouders van de gemeente Landerd ter zake van de verlening van een vrijstelling van het bestemmingsplan voor de bouw van een megastal. ${ }^{91}$ Hoewel dit schorsingsbesluit is genomen, net voordat de Wet revitalisering generiek toezicht en het bijbehorende Beleidskader in werking traden, is het besluit toch interessant. Gedeputeerde staten van Noord-Brabant lijken vooruit te lopen op het nieuwe art. 273a Gemeentewet, dat bepaalt dat gedeputeerde staten gemeentelijke besluiten kunnen voordragen voor vernietiging door de Kroon. Zij hebben mededeling gedaan aan de Kroon van het besluit van het gemeentebestuur van Landerd. Naar hun oordeel komt het voor vernietiging in aanmerking 'wegens strijd met het recht en strijd met het provinciaal (ruimtelijk) en dus algemeen belang'. Uit het schorsingsbesluit wordt niet duidelijk wanneer gedeputeerde staten van het besluit op de hoogte raakten; vermoedelijk is in afwijking van het nieuwe art. 273a die mededeling niet binnen een termijn van tien dagen gedaan. Het schorsingsbesluit volgt ruim twee jaar na het besluit van het college van de gemeente Landerd. 
Sinds de inwerkingtreding van de Wet revitalisering generiek toezicht zijn twee besluiten geschorst. Op 17 juni 2013 schorst de Kroon het besluit van de raad van de gemeente Voerendaal tot vaststelling van een beheersverordening. ${ }^{92}$ Hoewel niet geëxpliciteerd in het schorsingsbesluit, lijkt het erop dat in casu gedeputeerde staten gebruik hebben gemaakt van hun bevoegdheid ex art. 273a Gemeentewet om het besluit van het gemeentebestuur voor te dragen voor vernietiging. Ook enkele raadsfracties en burgers verzoeken tot vernietiging van het besluit. Volgens gedeputeerde staten maakt de raad oneigenlijk gebruik van het instrument van de beheersverordening, kleven daaraan juridische gebreken en is er sprake van doorkruising van het provinciale volkshuisvestingsbeleid, hetgeen strijd met het recht en het algemeen belang tot gevolg heeft. Het betreft toezicht dat voorheen tot het specifieke toezicht behoorde, namelijk een uit de Wet ruimtelijke ordening (Wro) geschrapte bevoegdheid van gedeputeerde staten tot het geven van aanwijzingen. Uit het schorsingsbesluit wordt niet duidelijk of het bestuurlijk traject van het Beleidskader is gevolgd. Het Beleidskader wordt in het schorsingsbesluit niet genoemd.

Op 19 juli 2013 schorst de Kroon een besluit van het college van burgemeester en wethouders van de gemeente Zoeterwoude tot vaststelling van een ruimtelijk uitwerkingsplan. ${ }^{\mathbf{9 3}}$ Ook hier dragen gedeputeerde staten het besluit voor vernietiging voor. Het genomen besluit is volgens gedeputeerde staten in strijd met een provinciale verordening en met het algemeen belang. Het gaat ook hier om toezicht dat eerder tot het specifiek toezicht behoorde. Ook uit dit schorsingsbesluit wordt niet duidelijk of het bestuurlijk traject van het Beleidskader is gevolgd.

Uit deze schorsingsbesluiten kunnen nog geen conclusies worden getrokken. Wel lijkt het erop dat de bevoegdheid van gedeputeerde staten om besluiten voor vernietiging voor te dragen, een 'succes' zou kunnen worden. Verder is het aannemelijk dat de betreffende gemeentelijke besluiten voorheen onder specifieke toezichtregimes vielen. Indien deze trend zich zou voortzetten, zou er daadwerkelijk sprake zijn van een revitalisering van het generieke toezicht.

\section{En de Awb dan?}

De grote afwezige in deze geschiedenis is de Awb. De bepalingen uit Titel 10.2.2 zijn, sinds hun inwerkingtreding in 1998, nauwelijks gewijzigd. De

Aanpassingswet derde tranche heeft wat details in art. 10:39 en 10:44 Awb veranderd. ${ }^{94}$ De wet Nerpe (Naleving Europese publieke entiteiten) heeft aan art. 10:39 een vierde lid toegevoegd. Art. 10:39 Awb bepaalt in lid 1 dat een besluit tot het verrichten van een privaatrechtelijke rechtshandeling niet kan worden vernietigd, vanaf 13 weken na bekendmaking. Het nieuwe artikellid verklaart dit artikel niet van toepassing indien vernietiging geschiedt wegens strijd met EU-recht.95 Voor (spraakmakende) jurisprudentie hebben de bepalingen amper gezorgd. De jurisprudentie over schorsing en vernietiging heeft namelijk vooral betrekking op het discretionaire karakter van de vernietigingsbevoegdheid (art. 268 Gemeentewet) en op de Beleidskaders ter interpretatie van de (grondwettelijke) vernietigingsgronden. ${ }^{\mathbf{9 6}}$ Alleen de zaakValkenswaard heeft specifiek op de Awb betrekking, namelijk op de uitleg van art. 10:42 Awb juncto 281 Gemeentewet (zie par. 2): in hoeverre staat het de Kroon vrij om in het vernietigingsbesluit aan te geven wat toelaatbaar is, zodat een vernietiging van het nieuw te nemen besluit kan uitblijven?

Wetenschappelijk debat hebben de Awb-bepalingen nauwelijks opgeleverd.97 In dat debat wordt vooral kritiek uitgeoefend op de inhoudelijke normering van de opeenvolgende Beleidskaders en op de revitalisering van het vernietigingsrecht. 
De bepalingen in de Awb staan niet ter discussie. De kritiek uit de jaren 1990 dat de Gemeentewet en de Awb op dit punt niet goed op elkaar zouden zijn afgestemd, is verstomd. ${ }^{\mathbf{9 8}}$ Opvallend is voorts dat de Wet revitalisering generiek toezicht voor harmonisatie van het bestuurlijk toezicht heeft gezorgd (nota bene in de Gemeentewet), terwijl harmonisatie toch één van de doelstellingen van de Awb was. Met andere woorden: zowel de Awb als de Gemeentewet voorzien nu in een algemene regeling.

Uit het voorgaande kunnen we afleiden, dat binnen het kader dat de Awb geeft, diverse toezichtsarrangementen met tegenovergestelde doelen kunnen bestaan: spontane vernietiging als ultimum remedium of juist gerevitaliseerd. De Awb geeft weinig richting aan een verdere concrete uitwerking van het bestuurlijk toezicht in bijzondere wetten en heeft kennelijk de wetgever daarin veel vrijheid willen laten. De afwezigheid van de Awb in het toezichtsdebat kan positief en negatief worden geduid. Positief, omdat de bepalingen in de Awb, zoals juristen dan zeggen, rustig bezit zijn geweest. Negatief, omdat de bepalingen aan de rechtsvorming niet of nauwelijks hebben bijgedragen. De Awb is, zo kunnen we concluderen, voor de ontwikkeling van het spontane vernietigingsrecht niet of nauwelijks van waarde geweest. Alhoewel je dat ook positief kunt uitleggen: de Awb als constante van het bestuurlijk toezicht.

\section{Noten}

1 Aan de provincies besteed ik slechts aandacht voor zover dat relevant is voor dit betoog. Dat is bijvoorbeeld het geval bij de vernietiging van besluiten van het provinciebestuur.

2 Zie art. 132 lid 4 Grondwet, 10:35 en 10:43 Awb en 268 en 273 Gemeentewet.

3 Kamerstukken II 1985/86, 19 403, nr. 3, p. 14.

4 Ibidem, p. 20.

5 Kamerstukken II 1991/92, 21 427, nr. 21, p. 1.

6 Ibidem, p. 2.

7 Ibidem, p. 3 .

8 Ibidem, p. 3-4.

9 Ibidem, p. 4.

10 Ibidem, p. 6.

11 Art. 8 lid 2 EHLA.

12 Kamerstukken II 1991/92, 21 427, nr. 21, p. 8.

13 Kamerstukken II 1993/94, 23 700, nr. 3, p. 183.

14 Kamerstukken II 1993/94, 23 700, nr. 3, p. 194.

15 Kamerstukken II 1989/90, 21 221, nr. 3, p. 4; PG Awb I, p. 19; uitgebreid 
R.J.N. Schlössels, S.E. Zijlstra, Bestuursrecht in de sociale rechtsstaat, Deventer: Kluwer 2010, p. 85 e.v.

16 R.J.M.H. de Greef, 'Inventarisatie spontane vernietigingsbesluiten van de Kroon 1993-2004', deGemeentestem 2006, p. 191-199.

17 Het onderzoek van De Greef bestrijkt dus een periode die net vóór de inwerkingtreding van de nieuwe Gemeentewet aanvangt.

18 Volgens De Jong is het aantal vernietigingsbesluiten echter redelijk constant gebleven. Weliswaar schommelt het aantal vernietigingsbesluiten, maar dat zegt, volgens haar, weinig over het vernietigingsbeleid van de Kroon. M.A.D.W. de Jong, 'Toezicht', in: P.P.T. Bovend'Eert e.a., Constitutionele normen en decentralisatie, Deventer: Kluwer 2011, p. 190.

19 KB 19 februari 2001, Stb. 2001, 117; KB 12 juni 2001, Stb. 2001, 289.

20 ABRvS 20 november 2002, $A B$ 2003, 2 en 3.

21 P.H. van der Tang-van Loenen, 'Ergernis en bevoegdheid', NJB 2001, p. 2049-205O; A.Q.C. Tak, 'Het KB Valkenswaard', NJB 2002, p. 664-665; P.H. van der Tang-van Loenen, 'Vernietigingsbevoegdheid ongeschikt als handhaving', NJB 2002, p. 665.

22 KB 10 mei 2005, Stb. 2005, 270 (Lelystad); KB 1 november 2006, Stb. 2006, 572 (Oirschot); KB 1 november 2006, Stb. 2006, 573 (Gorinchem).

23 ABRvS 27 juni 2007, JB 2007, 163, m.nt. Broeksteeg (Oirschot).

24 Noot Broeksteeg onder JB 2007, 163 (Oirschot); H.G. Warmelink, 'Interpretatief gerommel rond rekenkamers', NJB 2008, p. 450-453; H.G. Warmelink, 'Introductie gemeentelijke rekenkamers', in: P.P.T. Bovend'Eert e.a., Constitutionele normen en decentralisatie, Deventer: Kluwer 2011, p. 153159; D.J. Elzinga in zijn columns in Binnenlands Bestuur van 29 april en 10 juni 2005; Noot Kortmann onder de Gemeentestem 2005, 132 (Lelystad).

25 KB 7 december 2005, Stb. 2005, 634.

26 Bijvoorbeeld door L.J.A. Damen, 'Minister van Justitie rechter in eigen zaak', Ars Aequi 2006, p. 300-308.

27 Rechtbank's-Gravenhage 23 december 2005, de Gemeentestem 2006, 57, m.nt. Teunissen.

28 Damen 2006; S.A.J. Munneke, 'Ruim baan voor het schorsings- en vernietigingsrecht, en een beetje voor de rechter!', in: K.J. de Graaf e.a. (red.), Op tegenspraak (Damen-bundel), Den Haag: Bju 2006, p. 135-143.

29 KB 12 december 2006, Stb. 2006, 692.

30 ABRvS 23 januari 2008, JB 2008, 46, m.nt. Broeksteeg. Zie ook J.L.W. Broeksteeg, 'Spontane vernietiging', in: R.J.N. Schlössels e.a. (red.), JB Select, Den Haag: Sdu 2009, p. 513-527. 
31 Kamerstukken II 2005/o6, 30300 VII, nr. 75.

32 De Jong 2011, p. 191-192.

33 Het Beleidskader is van 21 augustus 2006. Op dat moment was het schorsingsbesluit Haarlemmermeer al genomen, alsook het schorsingsbesluit Limburg. Het vernietigingsbesluit in die zaak volgde enkele maanden later. In het Beleidskader 2006 worden ook het vernietigingsbesluit (Lelystad) en de schorsingsbesluiten (Oirschot en Gorinchem) inzake de rekenkamerverordeningen genoemd. Vernietiging van de rekenkamerverordeningen van Oirschot en Gorinchem vindt later, na het verschijnen van het Beleidskader plaats. Omdat deze zaken in het Beleidskader worden genoemd en kennelijk mede aanleiding daarvoor zijn geweest, heb ik ze in de voorgaande paragraaf behandeld, als aanloop naar het nieuwe Beleidskader.

34 Kamerstukken II 2005/o6, 30300 VII, nr. 75, p. 2-3.

35 Overigens maakt de minister niet duidelijk waarom de invoering van de Awb relevant is voor een nieuw beleidskader.

36 Ibidem, p. 6.

37 Ibidem, p. 8.

38 Ibidem, p. 8-9.

39 Ibidem, p. 9.

40 Ibidem, p. 9-10.

41 Ibidem, p. 10.

42 De Jong 2011, p. 192.

43 Art. $124 \mathrm{Gw}$ (autonomie en medebewind).

44 Zie slechts art. $125 \mathrm{Gw}$ (provinciale staten en de gemeenteraad staan aan het hoofd van de provincie en de gemeente) en art. $127 \mathrm{Gw}$ (zij stellen ook de verordeningen vast).

45 De Jong 2011, p. 195.

46 Broeksteeg 2009, p. 522; Munneke 2006, p. 136.

47 Munneke 2006, p. 136-138.

48 Broeksteeg 2009, p. 522-523.

49 Ibidem, p. 523.

5o Een uitzonderling is S.E. Zijlstra, Bestuurlijk organisatierecht, Deventer: Kluwer 2009. 
51 KB 20 november 2006, Stb. 2006, 615.

52 KB 10 november 2008, Stb. 2008, 443.

53 ABRvS 22 april 2009, JB 2009, 144, m.nt. Broeksteeg. Zie ook De Jong 2011, p. 196.

54 KB 22 maart 2010, Stb. 2010, 138.

55 ABRvS 2 maart 2011, JB 2011, 99, m.nt. Broeksteeg.

56 KB 25 maart 2011, Stb. 2011, 154.

57 ABRvS 25 juli 2012, JB 2012, 219, m.nt. Broeksteeg.

58 De Jong 2011, p. 203.

59 Bestuurlijke Werkgroep-Alders, Interbestuurlijk toezicht herijkt, Den Haag: ministerie van BZK 2005.

60 Commissie-Oosting, Van specifiek naar generiek, september 2007, www.minbzk.nl.

61 Kamerstukken II 2007/o8, 31200 VII, nr. 61, p. 7.

62 Kamerstukken II 2009/10, 32 389, nrs. 1-3.

63 Wet van 24 mei 2012, Stb. 2012, 233; inwerkingtreding: KB 13 juni 2012, Stb. 2012, 276.

64 Kamerstukken II 2009/10, 32 389, nr. 3, p. 4.

65 Ibidem, p. 5 .

66 Ibidem, p. 12-13.

67 Ibidem, p. 20.

68 Ibidem, p. 21.

69 Ibidem, p. 21.

70 Art. 278a lid 2 Gemeentewet.

71 Art. 278a lid 1 Gemeentewet.

72 Art. 278a lid 4 Gemeentewet.

73 Art. 273a lid 1 Gemeentewet.

74 Art. 273a lid 2 Gemeentewet.

75 Kamerstukken II 2009/10, 32 389, nr. 3, p. 22. 
76 Art. 1.6 van de Wet revitalisering generiek toezicht wijzigt de bijlage bij de Awb.

77 Kamerstukken II 2009/10, 32 389, nr. 3.

78 Bijlage bij Kamerstukken II 2009/10, 32 389, nr. 5; hierna: Beleidskader; of: Beleidskader schorsing en vernietiging.

79 Ibidem, p. 3.

80 Ibidem, p. 4.

81 Ibidem, p. 5 .

82 KB 12 augustus 2003, Stb. 2003, 332 (Heumen), een besluit tot verlaging van de prijzen van bouwkavels, aangenomen door de kleinst mogelijke raadsmeerderheid, werd mede genomen door een raadslid dat een direct persoonlijk belang bij de besluitvorming had (art. 28 Gemeentewet).

83 KB 10 mei 2005, Stb. 2005, 270 (Lelystad), hiervoor besproken.

84 KB 12 juni 2001, Stb. 2001, 289 (Valkenswaard), hiervoor besproken.

85 Beleidskader schorsing en vernietiging, p. 6.

86 Ibidem, p. 7-13.

87 S.A.J. Munneke, 'Het wetsvoorstel revitalisering generiek toezicht', TvCR 2011, p. 423.

88 S.A.J. Munneke, 'Het gerevitaliseerde vernietigingsrecht: hinken op twee gedachten', in: C.B.M. van Haaren-Dresens e.a. (red.), Interbestuurlijk toezicht, Nijmegen: WLP 2011b, p. 45.

89 Munneke 2011b, p. 48.

90 S.E. Zijlstra, 'Het wetsvoorstel Revitalisering generiek toezicht', in: C.B.M. van Haaren-Dresens e.a. (red.), Interbestuurlijk toezicht, Nijmegen: WLP 2011, p. 28. Zie ook: S.E. Zijlstra, 'Sanering van specifiek toezicht en revitalisering van generiek toezicht: Reculer pour mieux sauter?', NTB 2011, p. 43-50. Zo ook: R.J.M.H. de Greef en C.B.M. van Haaren-Dresens, 'Spontane vernietiging wegens strijd met het algemeen belang', de Gemeentestem 2011, p. 632-644.

$91 \mathrm{~KB} 12$ juli 2012, Stb. 2012, 318.

92 KB 17 juni 2013, Stb. 2013, 216, de Gemeentestem 2013, p. 387-388.

93 KB 19 juli 2013, Stb. 2013, 314.

94 Wet van 6 november 1997, Stb. 1997, 510.

95 Wet van 24 mei 2012, Stb. 2012, 245. 
96 Art. 132 lid 4 Grondwet; herhaald in art. 10:35 Awb. De vernietigingsgronden zelf staan echter niet ter discussie.

97 Overigens: men zou hieruit kunnen afleiden dat de Awb (het verloop van) de procedure van vernietiging inzichtelijker heeft gemaakt. Dan zou de vooronderstelling zijn dat er voor de inwerkingtreding in de Awb veel kritiek bestond op de procedure van spontane vernietiging en dat die kritiek na deze inwerkingtreding is verstomd. Uit de oudere handboeken gemeenterecht is mij dat echter niet gebleken; uit de parlementaire geschiedenis van de derde tranche Awb evenmin.

98 Zie vooral A.H.M. Dölle en D.J. Elzinga, m.m.v. J.W.M. Engels, Handboek van het Nederlandse gemeenterecht, Deventer: Kluwer 2004, p. 703-729 (zie ook oudere drukken van dit handboek, bijvoorbeeld uit 1999). 